\title{
Pragmatic localism uncovered: The search for locally contingent solutions to national reform agendas
}

\author{
Jon Coaffee *, Nicola Headlam \\ Planning and Landscape Discipline, School of Environment and Development, Faculty of Humanities, University of Manchester, \\ Oxford Road, Manchester M13 9PL, United Kingdom
}

Received 13 June 2006; received in revised form 11 June 2007

\begin{abstract}
This paper analyses the complexity and attempted pragmatism of current practices surrounding the management of current local government policy reform in England. In particular, it focuses on the tensions and contradictions between a national policy dynamic which seeks to encourage locally contingent solutions to be developed for localised problems, and the centralising tendencies of the national state which result in 'blueprints' and 'models' being developed for local policy delivery and a requirement to meet centrally derived targets. These assumptions are explored through the experiences of local government attempts to introduce innovative and experimental praxis in line with the complex cultural and political changes of 'modernisation' agendas advanced by the UK government. This is being rolled out by an overarching project of 'new localism' - an attempt to devolve power and resources from the central state to front line local managers, sub-local structures and partnerships and to deliver 'what works'. It is argued that new attempts at subsidiarity should be more flexible to local conditions rather than directed by national policy and that greater discretion and freedom should be given to local managers to achieve this task. Using the concept of 'pragmatic localism' and grounded examples from a recent initiative - Local Area Agreements - it is highlighted that there are signs that local state management of national policy could be becoming increasingly adaptable, enabling managers to deal with the fluid nature of ongoing public policy reform, although this is far from a completed project with many factors still constraining this change process.
\end{abstract}

(c) 2007 Elsevier Ltd. All rights reserved.

Keywords: Pragmatism; New localism; Complexity; Local government; Partnership; England

The project of harmonizing ideals and practical realities often falls to the organs of public administration. Because this task involves the application of general and fixed concepts (policies, law, standards) to particular and fluid practicalities (situation, circumstances, persons), those in public administration need strategies to deal with unusual or problematic cases. Pragmatism seems to offer such a strategy (Hildebrand, 2005, p. 345).

The real challenge is for politicians and public servants to change their perspective and to see the world

\footnotetext{
${ }^{*}$ Corresponding author.

E-mail address: Jon.Coaffee@manchester.ac.uk (J. Coaffee).
}

in a way that opens up the doors to more effective ways of working (Sorabji, 2005, p. 12).

\section{Introduction}

Pragmatism, philosophically speaking, is 'a belief that the only way of establishing truth is through practical application to establish what works out most effectively' (Haywood, 2000, p. 88). This conception of pragmatism is based on a view that learning occurs through experimentation and in more post-modern terms, the rejection of universal concepts and meta-narratives which order and explain knowledge in board terms. As Zanetti and Carr (2000, p. 433) argue of pragmatism: 'the core of the philosophy was the belief that individuals must act continuously 
in an experimental fashion, testing beliefs and concepts against existence. Pragmatists rejected transcendent absolute ideas that could not be confirmed by experience and action'.

Pragmatism has evolved as a key philosophical organising concept because of a core question faced in every society - how to balance idealised values with the practical realities of implementing such values (see for example Hildebrand, 2005). ${ }^{1}$ Whereas in recent decades conceptual ideas of pragmatism have received a good degree of attention in the social sciences, applied examples of such pragmatism as they occur in everyday practice have proved more elusive. This is an important gap given the founding principles of pragmatism in the late nineteenth century where 'propositions could only be judged by the result produced when put into practice' (Zanetti and Carr, 2000, p. 433).

In recent years, philosophical pragmatism has been increasingly utilised within studies of the public sector in an attempt to help explain, and make sense of, an increasingly complex and multi-scalar world and to 'offer some inspirational guidelines for the practice of humanistic geography' (Smith, 1984, p. 353). Within this context, this paper explores both the concept and practice of pragmatism as developed in the management of complex local government policy reform in the England over the past decade, highlighting the barriers to such pragmatism in situ. In particular, it focuses on the tensions and contradictions between a national policy dynamic which seeks to encourage locally contingent solutions to be developed for localised problems, and the centralising tendencies of the national state which results in 'blueprints' and 'models' being developed for local policy delivery and a requirement to meet centrally derived targets. This analysis will also unpack key tensions and contradictions which occur as a result of attempts to embed pragmatism within the wider framing of state policy: first, through the development of a broad underlying political mantra - the third way (Giddens, 1998; Blair, 1998) - representing a compromise position between the ideals of democratic socialism and laissez faire capitalism; and second through attempts to rescale the state by developing more effective relationships between the centre and locality which would allow the increased decentralisation of power and responsibility to local governments, but within prescribed limits - so-called new localism.

In this analysis, the concept of 'pragmatic localism' will be utilised to describe the desired state of affairs in local government policy and its relationship with central government. This idea has developed in recent years as a response to attempts by central government to deliver locality focused policy programmes combining innovation, creativ-

\footnotetext{
${ }^{1}$ There are numerous summaries of the philosophical nature of both classical pragmatism and its newer post-modern equivalent, neo-pragmatism (see for example Diggens, 1994; Hollinger and Depew, 1995; Dickstein, 1998) a detailed discussion of which lies beyond the scope of this paper.
}

ity and flexibility alongside a system of central 'guidance' focused upon performance management and 'best-value' targets. The argument here is for:

Pragmatism over prescription in local government policy - for a so-called 'middle way', which is inclusive of 'top and bottom' and acknowledges that you can have a local initiative and individual empowerment without the local state 'letting go'. Such an approach should have fewer targets and closer consultation with stakeholders to develop 'quality-based routes to excellence' as well as giving greater managerial discretion and flexibility to those in charge. In short, the argument is for a far more nuanced, 'pragmatic localism' where 'models' of change are replaced by 'ingredients', 'menus' and 'frameworks' of alternative methods of service delivery and community capacity building, which are selected according to local circumstances of place and not centrality prescribed targets (Coaffee and Johnston, 2005, p. 174).

The paper will argue that such attempts to manage change pragmatically, through the transformation of existing management and governance networks, is impeded by locally embedded institutional practices and political allegiances which affect how national policy guidance is interpreted and actioned on the ground. Here pragmatic change is intertwined with broader issues of public sector reform and cultural change.

This idealised concept of pragmatic localism provides a framework in which to explore particular policies developed within an overall period of reform and modernisation in the UK, and the reinvention of the central state which is occurring alongside change at other scales. In particular the process of transforming local urban governance through the embedding of a set of new principles intended to stimulate local partnership working and improve subsidiarity will be addressed. It is argued that this key reform is both premised upon implicit and explicit ideas of key managers and administrators acting pragmatically to balance a host of competing and often contradictory priorities to deliver 'what works' (Southern, 2001).

The rest of the paper is divided into five main sections. The first section will review the contribution of philosophical pragmatism to public administration, and in particular local government. The next two sections will subsequently highlight the various ways in which pragmatic ideas and programmes have been developed in local government policy in the previous decade. The following section will, in a more detailed way, present an emerging narrative of how pragmatism has been embedded within the particular policy frame of attempts to rejuvenate central-local government relations through developing Local Area Agreements (LAAs) - seen as a mid-range policy combining visionary strategy with the requirements for evidence based policy. The final section, the wider implications, for pragmatic localism praxis will be noted and linked to current and emerging national government priorities. 


\section{Pragmatic public administration}

Pragmatic thinking is vital in solving situationally specific problems and can be seen as 'a philosophy of experience' (Smith, 1984, p. 355). William James (1907) in Pragmatism: a new name for some old ways of thinking, noted that pragmatism was vital in a 'world of tangled, muddy, painful and perplexing, concrete experience'. John Dewey (1916, p. 167) in (Shields, 1996, p. 406) further argued that:

Ideas, as we have seen, whether they be humble guesses or dignified theories, are anticipations of some continuity or connection of an activity and a consequence which has not as yet shown itself. They are therefore tested by the operation of acting upon them.

For the public sector, such experientially based pragmatism as an organising principle is not a new concept, although through the 20th century it has tended to take a back seat to more rational, systemic, technocratic and scientific models of management which, for many, offered a more 'common sense' view of public administration. It is problematic though to present this technocracy as value neutral. Since the 1980s analyses of so-called New Public Management (NPM) reforms emphasise the coherence of ideologically driven waves of reform for efficiency as 'opening up' the public sector to neo-liberalising forces, competition and hybrid forms of delivery. This impetus can be seen in the hardwiring of business systems processes into the sector. Stever (2000, p. 457) however notes that despite views to the contrary, 'implicit pragmatism' (Snider, 2000) has embedded itself within many public sector programmes and organisational policy over time especially in times of 'crisis' and 'overwhelming challenges'. He highlights examples from the 1960s and 1970s American experience where implicit pragmatic public sector policy arose, under the label of citizen participation:

As the historical record indicates, both the citizenparticipation initiatives and managerialism adopted a pragmatic experimental/instrumental approach to organization building. These administrative initiatives were quite consistent with the premises that Dewey brought in institution building. Just because the advocates of these approaches did not properly label their efforts as pragmatic does not mask their pragmatic instincts and presuppositions (Stever, 2000, p. 456).

In short, as Bernstein (1992) highlighted, there is a 'pragmatic ethos' within the public sector, although this is often simplified and caricatured within many academic accounts that embrace critical theory to describe practice experience. Contemporary public sector managers are therefore often seen as pragmatists who have to navigate a fluid policy environment fraught with politics and infused with micro-power struggles. As Shields (1996, p. 391) has highlighted in relation to the North American public sector:
Public administrators practice in a world of paradox and contradiction, disorder and pattern. They may be required to narrow their focus and concentrate on rules and regulations. On the other hand, public administrators may need bargaining skills to ensure that organizational conflict is resolved. Public administrators also work in a turbulent world where politics matter, be it office politics, bureaucratic politics or battles between Congress and the administration.

Work on the social-psychological effects of working within these complexities for the 'frontline bureaucrat' (Considine and Lewis, 1999), demonstrates how far people and organisations react and respond to change and how pragmatic skill-sets are often required for success:

Perhaps there was a time when the term bureaucracy had a settled meaning and the institutions it defined had a standard purpose. If so this time has passed. In its place has emerged a variety of bureaucracies, temporary and fixed, public and private...this profusion of bureaucracies raises important questions concerning the work that bureaucrats do (Considine and Lewis, 1999, p. 467).

A key point here is the effect on the identity of those charged with negotiating and navigating an environment characterised by continual change and reform. Clearly a major factor is how far reforms are felt to constrain, or reduce the ability of managers to act pragmatically or professionally, and how far (and how quickly) modified actions and strategies are developed. The caricature of the capable, but cynical local authority manager 'weathering' whatever emerges, and concentrating on 'business as usual' is only one of the actor strategies delineated by Van der Pennan (2005) whose description of policy networks for urban governance in the Netherlands focuses on the varieties of ways that individuals within municipalities adopt new pragmatic strategies in order to attempt to balance procedural, process or material steering. Further empirical work with both frontline personnel and service managers has also sought to connect attitudes to waves of reform, arguing that 'a hybrid form of bureaucracy is emerging which combines some of the traditional procedural bureaucracy with flexibility, user focus and professional pride' (Berg, 2006, p. 556).

Shields (2004) has also articulated this idea through the notion of the pragmatic 'policy imprint' where public administrators take mandates, directives or guidance and translate them into workable policy on the ground - 'localising' is about strategies which successfully navigate the public policy mosaic and make local policy work; not just 'what works, but what works here'.

Others have illuminated a number of difficulties with applying such pragmatism to the study of the public sector given the ever-changing context that mediates the action of public administration professionals and, which makes experience contingent upon specific socio-historical con- 
texts and systems of language (Zanetti and Carr, 2000; Miller, 2005). Shields (2003) also argues that public administration, to operate effectively, requires what Dewey called a 'community of inquiry' - where it took cooperation between social institutions and communities of interest to solve emergent problems - but that this often fails to develop appropriately 'if members are fixed in their belief system and impervious to fresh evidence' (p. 511). In particular, many public servants are tied into to a system which values 'expertise' over 'experimentation' and hence fall back on assumed knowledge, old 'ways of doing' and abstract, often rationality or scientifically based, conceptual ideas, models or blueprints where what Garrison (2000, p. 468) calls the 'art of administration' - the ability to behave and act pragmatically and experientially - is lost. ${ }^{2}$

Developing new ways of working pragmatically should therefore be first and foremost a grounded practice. As Dewey (1916) in Stolcis (2004, p. 364) noted, 'an ounce of experience is better than a tonne of theory simply because it is only in experience that any theory has vital and verifiable significance'. It is this experience that helps practitioners to navigate the complex governance of the public sector - what Dewey called the "problematic situation' - and make appropriate choices and decisions, contingent upon context to the problems faced. This is a cyclical process with accumulated experience helping to constantly shape and reshape the practitioners' current frame of reference. This makes experience the key to the learning process, especially in unfamiliar and uncertain situations, where reflective action is required to deal with each unique situation. $^{3}$

In the last decade pragmatism has become a key idea within the study of public administration, especially in North America, as more adaptive and experimental approaches to managing complex and multifaceted agendas have been sought (Hildebrand, 2005; Shields, 2003; Stolcis, 2004). Such discussion has tended to centre upon the relative merits of classical pragmatism versus neopragmatism (also known as post-modern or linguistic pragmatism - see for example Rorty, 1982, 1991, 1999) and in the overriding concern for a liberal democracy and maximum freedom. In particular the conception of democracy as a shared communicative experience binds the works of both classical pragmatists (most notable Dewey and ideas of conjoint communicated experience) and neo-pragmatists (especially through the work of Habermas on communicative rationality and Rorty's linguistic pragmatism).

\footnotetext{
${ }^{2}$ This was especially the case through the interwar years with the rise of the scientific school of management, but has lingered within the public sector, still being present today, albeit to a lesser degree (see for example: Snider, 2000; Fry, 1989).

${ }^{3}$ Dewey in his later work referred to this as transaction - a refined version of interaction - where situation and contingent variables are seen as fluid (Elkjaer, 2004; see also Dewey and Bentley, 1949; and Bernstein, 1960).
}

Garrison (2000, p. 463) for example, highlights this consensus through the importance of the 'conversation', noting that, 'the quality of the conversation is what matters most in democratic society. If the conversation is free, open, diverse, and genuinely inclusive, the nation will prosper. $^{4}$

Classical and neo-pragmatism do however diverge on a number of points most notably the relative weight given to practice experience. In a post-modern twist some neo-pragmatists writing in the public administration field have argued that experience, given its situational nature is a concept about reality rather than the foundation of pragmatic thinking and action, as with classical pragmatism. ${ }^{5}$ In this sense neo-pragmatism of the Rortyian tradition is 'unabashedly non-empirical' (Shields, 2004, p. 358) and 'shares with post-modernism a rejection of the importance of factual evidence and experience in favour of discourses' (Webb, 2004, p. 481).

This paper very much takes the view, following Shields, that for public administration, 'thoughtful practitioners want a field rich in theory and academic rigor. They also want this theory to resonate with their professional experience and be useful in their everyday organisational lives' (Shields, 2004, p. 354). This is more akin to classical notions of Dewesian pragmatism which privileges the practitioner as opposed to followers of Rorty where for many 'there is a philosophical separation of discourse from experience that eliminates any practical usefulness of philosophy...' (Webb, 2004, p. 485).

In summary, public administration has utilised pragmatism both as a theoretical construct and also, but to a lesser degree, in practice. This field of research acknowledges the importance of experience in shaping unpredictable outcomes in a situation of fluid complexity and the need to seek solutions which are democratic and inclusive. Equally this field of inquiry is aware of the way in which power can corrupt the pragmatic process and the inherent tension within public sector management between statute/direction/guidance and creativity/flexibility/experimentation. The paper now turns to an empirically driven and theoretically informed account of the production and delivery of pragmatic local government in England over the past decade. In particular, this is informed by qualitative and survey research undertaken by the authors between February 2006 and February 2007 as part of an ongoing UK Economic and Social Research Council grant looking at issues of rescaling the state with specific reference to Local Area Agreements. ${ }^{6}$ This has involved in-depth grounded research in a number of local government set-

\footnotetext{
${ }^{4}$ Garrison further notes, importantly, that administrators must learn to listen as well as pronounce.

${ }^{5}$ See for example Miller (2005).

${ }^{6}$ This work has also been undertaken in conjunction with the Centre for Local Economic Studies (CLES), a local economic development consultancy based in Manchester, UK.
} 
tings, a series of conversations with key national and regional-level actors and a chain of 'user' workshops.

\section{A pragmatic polity: Searching for the middle way and what works}

In the past decade, English politics has been infused with a sense of newness, reform, modernisation and change (Driver and Martell, 1998; Powell, 1999). However, it is a radically different sort of politics and policy making process where it appears that the ideology of political ideas has taken a back seat to delivering successful policy on the ground and evidencing its impacts (Cabinet Office, 1999). In short, pragmatic polity is the order of the day. Pragmatism both frames the overall project embarked upon by Tony Blair's New Labour Government (19972007) as well as being a key feature, implemented through policy, of attempts to rescale the state, and in particular to modernise local government.

\subsection{The pragmatic third way: Between a rock and a hard place?}

Since the 1970s, the reform of public administration, linked to the need to transform the delivery of public services and modernise public institutions, has continued apace linked to emergent concepts of 'third way' politics - a normative agenda for centre-left politics throughout the Western world (Giddens, 1998; Page, 1991; Leach and Wilson, 2004). This approach, popularised in recent times by the Clinton administration in the USA, and the Blair government in the UK, has sought different ways to manage the complexities of the increasingly globalised world. As Scanlon (2001, p. 496) notes 'the third way has emerged from a more pragmatic concern about the extent and scope of state action and a desire to limit it to sustainable levels in order that government proceed in an effective manner'.

In many cases this has amounted to the vertical decentralisation of a varying degree of power and responsibility to different tiers of government premised upon the twin concerns of unleashing enterprise and market forces, whilst at the same time, ensuring the provision of key social support services (Coaffee, 2005a). In North America and Western Europe in particular, the recasting of government is ongoing based on principles of smaller, more efficient government units and, particularly in the European Union, on the idea of 'subsidiarity', with critical questions being asked about the future role, remit and geographical scope of subnational government given the broad consensus that it is at present 'overloaded' (Hambleton and Sweeting, 2004; Morgan, 2002; Loughlin, 2001; Scanlon, 2001). This was especially vital in the UK which is characterised by a high degree of centralism, perhaps unique amongst western democracies (LGA, 2006).

The third way theory of change - seen by many as a 'middle way' compromise position - has a number of key features which include: absorbing social democracy into neo-liberalism; embedding private sector organisational principles within the public sector; a belief in the value of community, the promotion of active citizenship and the importance of equal opportunity based on ideas of social capital and communitarianism (Putnam, 2000; Etzioni, 1998); an emphasis upon accountability, evidence and performance management; and, the appreciation of a 'stakeholder society' emphasising a broader shift in decentralised decision making, conceptualised as a transformation from 'providing' to 'enabling' state and from 'government' to 'governance' (Hutton, 1995; Wilson and Game, 2002; Rhodes, 1996).

The many facets of the third way have meant that its actual meaning has proved difficult to pin down leading to much confusion especially over terminology. As one commentator put it 'it is the Loch Ness Monster of British politics - everyone's heard of it, there are occasional sightings but no one is sure the beast actually exists' (Dickson, 1999). For many, the third way is viewed as ideologically uncommitted to either the left or right preferring to focus instead upon a broad mantra of 'what works' - 'a form of benevolent pragmatism - a philosophy that asked of each policy - is it good, does it work?' (Dickson, 1999). Indeed, Martin Powell (2000) has argued that the third way is little more than a new and distinctive approach that can be summed up by the phrase 'populism and pragmatism'. He noted in particular, that the third way had 'pragmatism at its heart' (p. 53) which can be identified through two key features:

First, the lack of a big underlying political philosophy underpinning the approach - in short, 'the big idea is that there is no big idea' - 'it is policy making on the hoof' (Powell, 2000, p. 53) which is essentially ambiguous and Janus-faced (Smith, 2001, p. 267). The third way for many is a 'principle free zone' (Maude, 1998 in Temple, 2000, p. 302) which 'allows unlimited ideological flexibility (and) the right to change policies as a matter of principle' (Temple, 2000, p. 310).

Second, the third way idea can perhaps be summed up by the well-worn phrase - 'what matters is what works' which has developed some claim as the underlying purpose of policy at the expense of tackling wider social and economic inequalities (Lister, 2001). Such an approach has been described as 'dogmatic pragmatism' (Clarke, 1999) in (Lister, 2001, p. 85) which 'represented a shift from a focus on the institutions of government to a focus upon the practice of governance' (Scanlon, 2001, p. 483). The 'what matters is what works' mantra was summed up by the then leader of the political opposition Tony Blair in the Labour Party's 1997 election manifesto:

We will be a radical government. New Labour is the party of ideas and ideals but not outdated ideology. What counts is what works. The objectives are radical. The means will be modern. Britain will be better with new Labour (emphasis added). 
When elected to power Blair, in the forward to the seminal social exclusion report entitled Bringing Britain Together (Social Exclusion Unit, 1998) reaffirmed this message:

Too much has been imposed from above, when experience shows that success depends on communities themselves having the power and taking the responsibility to make things better. . . the lessons haven't been learned properly. A new approach is long overdue. It has to be comprehensive, long-term and founded on what works (emphasis added).

In summary, the third way therefore represented a move from ideology to output politics (Temple, 2000) where political philosophy was less important than good management and the search for creative, innovative, inclusive and flexible solutions to the complexity of the public sector. As Temple further notes (p. 320), 'the answer depends not on the provision of a universal mechanism from a relatively fixed ideological position but on the best way to achieve a desired end' (emphasis added).

\section{The localism delivery vehicle - situational pragmatism or new centralism?}

The pragmatic philosophy of the third way has been utilised in developing a host of English local government policy under the broad banner of what is commonly referred to as 'new localism'. This was linked to a wider modernisation of local government which emphasised decentralisation, and the increased role of community participation in decision making ${ }^{7}$ so that local systems of working, and their administrators could act in more flexible and responsive ways.

Such change was often articulated in terms of the complicated and ever-changing nature of central-local government relationships. Local government, as key cornerstone of the third way, was asked to develop a flexible enabling role, with changing managerial positions reflecting pragmatism, accountability and transparency, alongside wider consultation with citizens/customers. In short, bottom-up approaches were favoured over top-down directive approaches, with central government providing both the funding and encouragement for locally focused strategies to take root, paving the way for the recent explosion in new styles of partnership, area based initiatives and networking at the local level (Wilson, 2003; Coaffee and Johnston, 2005). In this vein, Pratchett (2004) also argued that new localism can perhaps be seen as an attempt to manage and to 'clarify some of the complexities that bedevil central-local relations' although its capacity to resolve this dilemma seems limited.

New localism as a delivery vehicle for the ideas of third way has been driven forward since 2002 by the influential

\footnotetext{
${ }^{7}$ This placed a particular emphasis on local governments to produce what was known as a Community Strategy (DETR, 2000). See also for example DETR (1998); Local Government Act 2000.
}

public policy 'think tank' the New Local Government Network (NLGN). ${ }^{8}$ To the NLGN new localism was a strategy which aimed at devolving power and resources away from central control and towards local front line managers, local democratic structures and communities but within an agreed framework of national policy priorities and minimum standards (Corry and Stoker, 2002; Corry et al., 2003). Stoker (2004, p. 118) also argues that new localism is at its core a pragmatic and experimentally driven response to emerging local government complexity:

New localism represents a practical response to a significant practical challenge: how to manage a substantial variety of state service provision and interventions in a world that defies the application of simple rule-driven solutions and often requires an effective response from the recipient of the service or intervention in order for the state to action work.

For the NLGN this role was to be played out in a plural fashion; with partnerships evolving into forms of "networked' local governance. They argued that network governance is both possible and desirable and that employing the network as metaphor is helpful for characterising contemporary governance arrangements.

Other commentators have accused both networked governance and new localism of paradoxically being a form of new 'centralism' (Lowndes, 2003). ${ }^{9}$ In this vein, a much maligned aspect of this process has been the notion of 'earned autonomy ${ }^{10}$ which refers to the way in which the national government seeks to reward top-performing local governments, giving them additional 'freedoms and flexibilities' (now called enabling measures) and 'discretion' to develop and reform as they see best, and in accordance with evidenced local priorities, but alongside a commitment to the meeting of national standards. However, failure to meet such standards will, more often than not, see the removal of such discretion. ${ }^{11}$

In this sense new localism involves a prescriptive or steering role for the national state which sits in contradic-

\footnotetext{
${ }^{8}$ New localism in the early to mid-2000s was seen as the 'main organising principle of sub-national governance. It was seen as a means of improving democratic accountability, providing a local mandate, and producing inter-agency approaches to localities' (Morphet, 2004, p. 293).

9 This differs from previous UK localist government initiatives in the 1970s and 1980s, such as the 'going local' experiments (Boddy and Fudge, 1984; Diamond, 2004) where the local state was perceived as the legitimate 'provider' of all essential services. Under the new localist conception the role of the local state is now very much seen as that of 'enabling' and 'ensuring' (Coaffee, 2005a).

${ }^{10}$ Also referred to as constrained discretion, steering localism or decentralisation by degrees.

${ }^{11}$ More critically, Powell (2004) sees new localism as 'ultimately the cousin of the centralist approach' and as a key feature of New Labour's managerial style. Under New Labour the number of inspectors auditing, evaluating and scrutinising local state service delivery has recently seen a rapid growth as regimes of 'Best Value' and performance assessment become central to the modernisation of local government.
} 
tion to the pragmatic intentions of wider polity. At the local level this inevitably creates problems and tensions within a multi-level governance framework as there is a requirement to both centralise to get strategic focus and meet performance targets, as well as for devolution and decentralisation to gain stakeholder inclusivity and innovative local solutions to local problems (Coaffee and Healey, 2003). As Pratchett (2004, p. 373) further notes:

\section{National government are caught. .. in a paradox. On the one hand, strong local autonomy is essential to maintaining the local democracy practices that underpin broader democratic cultures within the pol- ity. On the other hand, local autonomy threatens the viability of democratically supported national priori- ties. Too much local autonomy, in this sense, can destabilise the national institutions of democratic government.}

In essence, new localism is about trying to achieve a pragmatic balance between the competing forces of localism and centralism (Coaffee, 2005a). Wilson (2003) however argues that despite the appearance in the local political arena of new forms of participation and stakeholders, the influence in policy making terms is still located at national level giving recent UK public sector reforms a distinct appearance of 'control freakery'. As such, national government appear to 'offer local government the impression that it is being drawn into a new partnership (promising influence, increased powers, financial latitude) to distract it from the reality of increasing central control (reflecting the centre's lack of trust) but do so in a highly conditional way by rewarding the top performers - hence the focus on earned autonomy' (Wilson, 2003, p. 342).

The management of public administration has been the key target of the new localism policy drive, although empirical accounts of how this dynamic has developed in praxis are few and far between, with notable exceptions (Randle, 2005; Coaffee and Johnston, 2005; BURA, 2006). The key point here is that new localist policy has been pragmatic in emphasis but mediated by a double power-relationship between central and local government and between local government and its communities and stakeholders which has impacted upon the delivery of effective policy on the ground (Coaffee, 2004). ${ }^{12}$

It is this indecision and ineffective delivery that has encouraged the call for a more nuanced 'pragmatic localism' (Coaffee and Johnston, 2005) which allows local experimentation, innovation and creativity to be developed outside of tightly controlled central guidance and where 'flexibility demands a willingness to allow small-scale local

\footnotetext{
${ }^{12}$ Added to this is the further issue that within the multi-level polity the 'steering role' (or, the role or being in a position to constrain the pragmatic response of another, nested layer) has often been devolved only as far as the regional tier.
}

experiments that deviate from a multi-agency norm' (Temple, 2000, p. 320).

The next sections of the paper will detail more recent government attempts at increasing such locally focused pragmatism through the development of new mechanisms to rescale the national state and empower localities, and in particular a key English government initiative - Local Area Agreements.

\section{Pragmatic local delivery vehicles and strategies}

In the last decade in England, numerous local delivery vehicles (LDVs) have been instated at local government level which promotes the importance of multi-stakeholder partnership, local autonomy, and importantly, pragmatic ways of working in accordance with local contingency. The umbrella LDV for a plethora of area-focused initiatives was termed a Local Strategic Partnership (LSP) which aimed to: 'bring together at a local level the different parts of the public sector as well as the private, business, community and voluntary sectors so that different initiatives and services support each other and work together' (DTLR, 2001, p. 7).

One of the primary functions of the LSP was the development of a dedicated Community Strategy. Community Strategies were first introduced in the Local Government Act 2000, and placed a duty on local governments to prepare strategies for promoting or improving the well being of their areas, in broad terms, related to the underlying objectives of pragmatic third way policy - that is, enhancing enterprise and economic development with the promotion of sustainable social services. ${ }^{13}$ Community Strategies were required for local authorities initially in the 88 most disadvantaged areas of England in order to galvanise the promotion of partnership working and enable them to think strategically and in a long-range fashion.

The underpinning principles of Community Strategies were that they engage and involve local communities and when prepared were implemented by a LSP. The Community Strategy could therefore be seen as a 'plan of plans' or 'overarching policy statements for each council' (TewdwrJones et al., 2006, p. 537).

Community Strategies (which in 2004 were rebranded Sustainable Community Strategies) as they have developed in most English towns and cities became a visionary

\footnotetext{
$\overline{13}$ Guidance on Community Strategies defined their aims as fourfold: allow local communities (based on geography and/or interest) to articulate their aspirations, needs and priorities; co-ordinate the actions of the council, and of the public, private and voluntary and community organisations that operate locally; focus and shape existing and future activity of these organisations so that they effectively meet community needs and aspirations, and; contribute to the achievement of sustainable development both locally and more widely, with local goals and priorities, relating, where appropriate, to regional, national and even global aims (DETR, 2000, p. 2).
} 
document without a sufficiently powerful delivery vehicle (LSP). ${ }^{14}$ Here local deep seated political and institutional inertia often thwarted such strategic development. Rowe's recent (2006) work on 'abusive partnerships' narrates that LSPs in developing their Community Strategies, contrary to feeling like enabling and pragmatic spaces, are prescribed and directed from above, where partnerships act to 'airbrush out' legitimate political difference resulting in bland pronouncements where only the least contentious elements make it to the final document. Others have also shown how political and institutional inertia may thwart strategic development and restrict the extent to which local government and its partners could operate pragmatically and without being constrained by national government guidance (Coaffee, 2004; Bailey, 2005; Tewdwr-Jones et al., 2006). Davies (2004) also flags up this issue, describing the contemporary as a 'punctuated phase' of partnership working:

Partnerships are unstable ensembles where values clash, interests differ, state-centred hierarchies persist and a stable path-dependent trajectory seems elusive. Arguably, then we are in a punctuated phase and the growth of informal network styles of governance is but one possible outcome (p. 570, emphasis added).

Here, once again, the idea that an LSP represents a form of networked local governance or new localism is challenged as now apparently locally pragmatic structures are steered, where 'Central government defines the rules of the game by setting targets, requiring the preparation of strategies and delivery plans, and by ensuring that LSPs only become eligible for additional resources if their membership and other criteria are met through a process of accreditation. In other words they are a top-down intervention aimed to achieve local network formation' (Bailey, 2003, p. 445).

Contemporaneous with the LSP 'experiment' to create a 'plan of plans' strategic vision another centrally generated policy - this time focused upon 'measurement' not vision was developed as Local Public Service Agreements (LPSAs) and were designed and piloted within 20 local authorities between 2000-2002. LPSAs trade in detailed, specific and measurable improvements in performance, and tightly defined and controlled performance management. Key to the LPSA is the arrival of so-called 'stretch targets' - these are targets which have proved difficult to achieve and where a partnership can request additional or pooled/aligned funding and/or seek to negotiate increase pragmatism through being granted 'freedoms of flexibilities' in how they undertake existing processes. In short, LPSAs 'supposedly focus on the outcomes of service delivery rather than processes, inputs or outputs, However, evaluation evidence suggests that defining robust perfor-

\footnotetext{
${ }^{14}$ In areas outside of the original 88 poorest areas, the development of strategic visions without sufficiently powerful LSPs has led to the production of deeply flaccid Community Strategies.
}

mance indicators that accurately reflected desired outcomes became problematic...many national indicators were not themselves outcome measures but throughputs and outputs' (Sullivan and Gillanders, 2005, p. 561). LPSAs did not trade in visions but the very prosaic, detailed business of performance improvement.

The LPSA experiment demonstrates the same frustrations articulated by many of the LSP evaluations. Here pragmatic localism was being constrained by action at other spatial scales - in this case pressure from prescriptive national government guidance sent to local government, and the difficulties local government were having around identifying and working with a range of 'partners'. Young (2005, p. 16) for example, argues that 'working in partnership has long been a source of frustration for both central and local government. Although authorities are now encouraged to extend partnership working throughout the LSPA there is a basic lack of symmetry involved; the heart of the LPSA is a bilateral agreement between the two principal parties which can only be achieved through multilateral action on the part of several local partners'.

What became clear was that the visions of the (Sustainable) Community Strategy and LSP were colliding with the detail of the LPSA, both lacking in the necessary 'symmetry' between central-local action and co-ordinating with partners. What is critical though from this last wave of networked, new localist innovations is how they tended ignore the 'middle range'. It is here, between the vision and the detail, that new mechanisms are necessary. One such mechanism to emerge recently has been the Local Area Agreement, seen in some quarters as 'LSPs with teeth' but actually mechanisms to galvanise this 'mid-range' between overarching visionary strategy and performance managed number crunching.

\subsection{Rescaling governance through Local Area Agreements (LAAs)}

For decades the bureaucratic relationship between central and local government and the multiplicity of fragmented funding streams channelled to local government have been criticised, with constant calls made for streamlined funding and increased local autonomy over local decisions. In July 2004 the UK government launched a new 'pilot' governance initiative in England - LAAs - as part of a wider ten year 'Local Vision' strategy to alter the established relationships between central and local government (CLES, 2005; Sorabji, 2005). LAAs: a prospectus (ODPM, 2004), according to central government, heralded 'a radical new approach' to 'improve co-ordination between central government and local authorities and their partners', giving a stronger role to LSPs (ODPM, 2004, p. 5). Initially, LAAs were a three year statement of intent that set out local priorities as agreed through negotiation between local and central government, and were a reaction to the failures of existing Community Strategies which cre- 
ated a vision for change but often did not operationalise delivery.

LAAs, by contrast, focused on local priorities through establishing a comprehensive baseline performance position and developing targets, outcomes and indicators to be met. LAAs were intended to provide a further mechanism to complement existing LDVs such as LSPs and LPSAs, through which to coordinate a range of grant regimes from various central government departments which up to now had been channelled to different LDVs which serve the same population.

Central to the philosophy of LAAs was embedded pragmatism and a realisation that there are no 'one size fits all' solutions (LGA, 2005). For example, the LAA prospectus, unveiled by national government in July 2004 argued that LAAs:

...will help devolve decision making, moving from a 'Whitehall knows best' philosophy and reducing bureaucracy. This should allow efficiency gains... (but) will undoubtedly require central government departments to be more willing to let go of detailed day-day control of their programmes. Central government will continue to set high level strategic priorities and targets. But they will need to allow local authorities and their partners to decide jointly which local priorities best reflect local circumstances, while still contributing to the achievement of national targets (ODPM, 2004, p. 1).

Pragmatism was to be embedded in LAAs, in theory, in a number of ways: first, a focus upon priorities agreed between the local authority and LSP which allows the tackling of local problems in a coordinated way; second, under-spent resources could be carried over to the next year meaning there is less pressure to spend at the end of the financial year; third, LAAs were to have reduced bureaucracy and fewer monitoring requirements and hence reduced administrative costs; fourth, there was to be enhanced freedom to pool funding and set local priorities with other organisations/partners including joint priorities with other adjoining local governments; fifth, pragmatic capacity could be improved through the granting of additional freedoms if the local authority can evidence the case for enhanced flexibility through improved outcomes. This will allow local priorities to be targeted in a way that best suits local government; sixth, incentives were given through the meeting of central government priorities - so-called 'stretch targets', which if reached will allow 'reward' grants to be paid and further freedoms and flexibility granted; and finally, seventh, LAAs would give increased opportunity for local people to influence decision making, enhancing local democracy.

The theory of LAAs appears to be one that embraces the elements of pragmatism, and associated innovation and experimentation. As such, McInroy, a senior local economic development consultant (cited in Carpenter, 2005, p. 16) noted of LAAs that:
This is new localism in action...You can experiment more. ...You can pool and align funds, you can get new money through the reward element, and that money can be a clear catalyst for change....You can also collapse some of the bureaucracy of the LSP into the agreement.

LAAs were also implemented to provide an additional means of integrating the work of different tiers of government, and a range of service providing agencies and community and voluntary sector groups. In particular, LAAs aimed to reconcile the long-standing and often competing priorities of central and local government in respect to the delivery of local services, recognising the democratic mandate and leadership role of local authorities and central government objectives of maximising effectiveness and efficiency and demonstrating 'best value'.

LAAs clearly met the needs of local authorities frustrated by the polar opposite approaches of LSPs and LSPAs and the extraordinary challenge of integrating the two approaches into corporate planning and shared delivery plans with partners. When Central Government asked for volunteers to enter into a pilot phase of the LAA, 21 pilots were set up. Importantly, only one, of these (Telford and Wrekin) tried a radical 'single pot model'. The other 20 pilots were set up to comprise three 'blocks' (Children and Young People, Healthy Communities and Older People and Safer and Stronger Communities) all rooted in the key business of the public sector as a whole, subject to recent legislation and policy guidance, and, whose initial evaluations had highlighted a culture of co-commissioning and pragmatic working.

LAAs were to work by pooling and consolidating a variety of funding streams into one of these 'blocks', which, simplified and streamlined the local authority budget. By contrast, previous Community Strategies had focused upon a vast number of, often poorly coordinated, themes. Importantly, the measurement of success was to be dependent upon overall 'block performance' and not stream specific targets. This reduced the audit burden upon local agencies whilst also allowing institutional flexibility - pragmatism - in pursuit of LAA objectives and what local people needed. More broadly, it was argued that LAAs acting in this manner could enhance the power of local government and 'trigger a renaissance in the ambition of local government' (Sorabji, 2005, p. 12).

Despite the foundations of the existing statutory plans and policy directions, the lessons from the early wave of the LAAs pilots indicated that localities struggled with the LAA process. The process evaluation, undertaken by central government described the process as 'like eating a cloud with a knife and fork' (DCLG, 2005, p. 21) referring to the continual and complex changes that emerged:

When they embarked upon the process, local authorities and their partners we unaware of the scale and nature of the task in front of them; they had no clear 
vision of the end product, no timetable or milestones and were aware that the 'ground rules' for the process would need to be made up as they went along (DCLG, 2005, p. 6).

An obvious early change was that a 'fourth block' was hastily included since pilot localities found that there was nowhere within the LAA for them to 'situate' their regeneration and economic development work.

The second wave of 66 further LAAs were signed off the following year (2006/7), mainly with the new expanded four-block structure in place. It should be pointed out that the potential to be a 'single pot' LAA was encouraged but ultimately restricted to those local authorities' who could demonstrate good or excellent performance assessment credentials. Given such encouragement, some first round pilots (such as Brighton and Hove) abandoned the blocks to become single pots. The single pot is the more radical and ultimately more pragmatic extension of the policy, whereby all public sector monies could be pooled for strategic planning purposes. In reality, however, LAAs have largely only succeeded in aligning very small amounts of discretionary funding. ${ }^{15}$

The second phase of LAAs was rigorously evaluated and the benefits of the pilot and second phases analysed. Results have proved inconclusive, although LAAs have now become a cornerstone of wider local government modernisation pursued by the national state. In particular, tensions have emerged over the alleged efficiencies promised through LAAs and the initial high-cost of setting up, staffing and consulting on the new governance arrangements. This is highlighted even in the Government's own evaluation:

...to date, we found few signs of efficiency gains from the LAA process - indeed so far the converse has been true in our case studies. Whilst there has been little reduction in performance management and reporting, the preparation and negotiation process has resulted in a huge increase in workload at all levels in the system (DCLG, 2006, p. 7, emphasis added).

Despite this warning about their resource intensive nature, the LAA is being heavily promoted as a mechanism for efficiency and for streamlining performance management burdens. Initial evidence therefore suggests that LAAs were being seen as 'problem-solving tools' within local government with a suspicion that the pragmatic rhetoric of LAAs, especially the promised enabling measures, is more impressive than the practice reality (CLES, 2005).

\footnotetext{
${ }^{15}$ This development of a single pot model is important, as most recent legislation has meant that LAAs had to be agreed within all top-tier authorities by April 2007 and that by 2009 all local authorities should be operating such Single Pot LAAs, despite concerns over how successful this will be in practice.
}

\section{Fostering pragmatic practice in the public sector}

The recent rounds of local government management reform in England have focused upon a pragmatic vision of merging economic growth with the maintenance of social support services and an increasingly deliberative democracy. In particular, this vision was seen as best achieved through the decentralisation of power and responsibility to local service providers who were in a better position to identify local priorities and needs. Such a localist-driven system, it was argued, would also reduce bureaucracy and embed pragmatic ways of working into the public sector through increasing the opportunity for civil servants to act with increased flexibility and creativity and to engage with a full range of community and stakeholder groups. Despite these ambitions, plans to deliver 'what works', in practice such attempts at localism - in particular those identified in this paper - through LAAs - have not, as yet, been as successful in practice. In short, the reality, to date, does not meet the rhetoric.

That said LAAs have demonstrated the possibilities of new pragmatic ways of working although it is too early to judge the success, or otherwise, of the initiative. If 'what matters is what works' in 'pragmatic localism' the reforms stimulated by the introduction of LAAs should more properly be judged by the degree to which they meet their agreed outcomes and targets at the end of the initial pilot timeframe. What however is clear is that such initiatives have sought to improve the democracy of decision making through instigating increasingly inclusive governance arenas. The belief here is very much pragmatic with an emphasis on a 'shared communicative experience', the importance of 'the conversation' (Garrison, 2000) and a negotiation of equals in what Dewey termed a 'community inquiry' where pragmatic outcomes can be negotiated-out. For example, for LAAs, there is evidence that the 'single conversation' that used to be heard emanating from central government is becoming a 'joint conversation' (LGA, 2005, p. 23). This, in time, will hopefully allow increased opportunity for local government to negotiate targets and priorities with community partners and central government - with an overall acceptance that there is no 'one size fits all' solution.

The increasingly local and pragmatically oriented local government change agenda and the advent of LAAs, is also bringing about a review of partnership processes and in many cases reveals a new level and intensity of partnership working - the momentum of which needs to be maintained. In particular there has been a root and branch rethinking of the role of the umbrella local delivery vehicle (the LSP) which for many, added increased bureaucracy to local government decision making. Importantly, it is now expected that delivery be creative, proactive and helpful for communities wishing to shape their own destinies. Such reform is however essentially about promoting a change in culture, and in particular, strengthening the capacity of local government to actively engage with the community and an array of stakeholders/partners. 


\subsection{What matters is what works verses constrained localism}

Despite the emergence of some innovation, creativity, local accountability within the local delivery of public services, this highly complex policy arena has in a number of ways proved resistant to more advanced pragmatic working, and in so doing, created a type of constrained localism. This is perhaps for a number of key reasons.

First, there is still a large number of local government initiatives and partnerships being established, often at pace, and without due care being taken to match them with local priorities and cultures of working. Many localism initiatives have to trade off inclusivity within the decision making process, especially around the complex issue of community engagement, versus the need to keep to the delivery schedule of a particular policy. In many cases, fear of programme slippage (and the resultant penalisation) means that innovative thinking and community involvement falls back on old patterns of tokenistic inclusion. In practice, this has meant that many such partnerships have so far failed to add value to the change management process or result in faster and more effective policy delivery (Bailey, 2003). Such uncritical policy transfer is unfortunately an all too common feature of UK urban policy development as local government is put under pressure to quickly develop and implement national policy guidance. As such 'policy is often applied prescriptively or pulled off the shelf and mapped uncritically onto a particular organisational landscape without due care' (Johnston, 2005, p. 74).

Second, there is a critical question of who is in change of local policy responses - central or local government? Often there appears a reluctance of national government to 'let go' and allow local government to act pragmatically and develop locally contingent solutions to problems rather than feeling compelled to fit with guidance. Central government in this sense is not practicing what it preaches. This amounts to 'pragmatism within limits' where initiatives are forced to develop in particular ways or make strategic connections, in line with centrally prescribed guidance, due to concerns about meeting target objectives. This lack of local empowerment has been a problem for LAAs. For example some worry that LAAs are becoming caught in 'another skirmish between centre and locality' (LGA, 2005 , p. 23) with wide-scale frustration of central government blocking the flexibility and freedoms suggested by LAAs (Lyons Inquiry, 2006, p. 11; CLES, 2005). There is still intransigence to change the central-local relationship. Responding to such criticism that central bureaucracy is slowing LAA progress, the Local Government Minister in 2006 noted in relation to the strategic leadership role of local government in place making, that: individual departments and civil servants need to accept the underlying principle that the local democratic body... knows what is best for the local area' (Vize, 2006, p. 8).

Third, there is a hidden or 'dark side' of pragmatic policy response, often rooted in the history of local gover- nance traditions, where embedded power relations often strongly influence outcomes. Understanding the increasingly complex local networking of power is a key feature in determining successful pragmatic strategy making (Taylor, 2003). Whereas new initiatives such as LAAs have been beneficial for developing a 'menu of coping' in what Dewey called the 'problematic situation', established 'rules of the game' or old assumptions are often fallen back on. The emphasis on experience here is a double-edge sword. On one side experience is vital for navigating the embedded institutional environment. On the other side, experience is often equated with embedded practices and a degree of institutional inertia. This can of course be overcome, at least partially through dedicated training and skill development. The critical question for new and pragmatic localism initiatives is: are they actively creating 'new spaces of hope' or just 'restabilising old regimes' (Coaffee and Healey, 2003; Coaffee, 2005b) where local power-struggles often inhibit change from old patterns of working? This concern was very evident in LAAs where some argued that:

The challenge for the next phase will be to build on the innovation and creative thinking that has emerged in the pilots. . In the process of embedding what has started as a radical new way of working, there is always the danger that the embedding will dilute the radicalism. The basic simplicity of the thinking behind LAAs, of collective focus on making a difference... must not be lost (LGA, 2005, p. 24).

There is no question that the LAA has had a rapid evolution, out of the 'policy primeval soup' of local government modernisation (Lowndes, 2003) to come to centre stage within the recent Strong and Prosperous Communities Local Government White Paper (DCLG, 2006). There is now potential both for the LAA to resolve some of the issues and tensions highlighted by LSPs and LPSAs - which hare now both integrated in the LAA process - and for emerging as functional examples of networked local governance with the resources of partners freed up to meet local needs and priorities as demonstrated by robust evidence. ${ }^{16}$ For example, the most recent pronouncements on implementing the 2006 Local Government White Paper has sought to make LAAs 'the main delivery agreement between central government and a local area' and in line with a new national performance management framework to be developed (DCLG, 2007a, p. 18). Such new LAAs (to be introduced in April 2008) are now seen by national government as a panacea, which might solve the historically intractable tensions between different tiers of government:

Our ambition is for LAAs to provide local authorities and partners with the flexibility and capacity to deliver the best solutions for their areas through a

\footnotetext{
${ }^{16}$ This process is mediated at a regional level by Government Offices in the regions.
} 
reformed relationship between central and local government (DCLG, 2007a, p. 5).

This assumption is premised upon 'the overwhelming message' of benefits, particularly to partnership working emanating from the 87 areas (as of February 2007) with a signed LAA. This message however, should not be read as a carte blanche endorsement of LAAs. Furthermore, the results of another government consultative evaluation published in early 2007 highlighted that to date there is little cost saving associated with LAAs and 'very little evidence to date of significant efficiencies through streamlining or rationalisation...' (DCLG, 2007b, p. 5). The message that appears from many local managers charged with developing and delivering through an LAA is different with much concern being expressed that the implementation of new and increasingly complex LAAs is being rushed and its supposed benefits not, at this time, backed up by constant evidence or everyday experience of added value. As LAAs evolve further their effects will need to be closely examined to see if the policy promise of locally facing devolved networks empowered to steer and to act pragmatically are mechanisms which enable the 'place shaping' and 'sustainable communities' they were designed to deliver.

\section{Conclusions}

In the public sector, acting pragmatically - the practical application of what works - involves compromise, experimentation, creativity, innovation and the ability to work across conventional boundaries in new strategic alliances and networks, and with non-conventional partners. It rejects prescriptive accounts, blueprints or models of change and instead focuses, in complex policy arenas, upon providing a menu of alternatives, selected according to local contingency and in line with a deliberative democracy. As Dryzek (2004, p. 72) has noted, pragmatism is central to the creation of deliberative publics:

Pragmatism sees continuity between the problemsolving efforts of experts and lay citizens. All problem-solving is experimental inquiry under conditions of uncertainty, and involves a number of inquirers rather than the solitary thinker. Social problem-solving in particular features an ever-changing agenda to which particular sorts of expertise may be relevant, but for which any single sort of expertise is rarely conclusive.

Whereas this approach, at least conceptually, is embedded within much of current local government policy in England, the reality of the implementation of such an approach does not, as yet, meet the goals of a real and enlightened pragmatic localism in practice.

Attempts at pragmatic working which have sought to refashion the management of the public sector by transforming governance arrangements between central and local government and between local government and its communities, are increasingly occurring through specialised initiatives such as LAAs, but which have at present not transformed, but merely destabilised, the 'existing order'. None-the-less these initiatives shows signs of beginning to experiment and leave behind what Shields (1996) called a pragmatic 'policy imprint'. For example research conducted on LAAs to date has noted that 'the freedoms and flexibilities agreed were not massively transformational but instead tended to tinker on the margins of service delivery and working practices with deeper impact expected in the longer term' (CLES, 2005, p. 9). Equally, impacts were seen as experimental rather than evaluative and in some cases 'leading to the development of good working relationships between local partners and...a belief that the process...would be significant in facilitating working relationships and contribute to improved learning' (ibid.).

What has emerged in the English public sector is a commitment to pragmatism, but within limits, which is mediated by guidance and evaluated by a multitude of targets in a culture of evidence-based testing and 'central steering', leaving a conflict between 'robustness' of delivery versus 'revisability' of policy (Lowndes and Wilson, 2003). In such a scenario it is more often than not, the innovative, experimental and pragmatic elements which contribute to the ability of a partnership to generate in-built flexibility that appear to be 'designed out' of new institutional modes of governance through the need to 'prove' impact results and evidence delivery targets (Coaffee, 2005a,b). In the UK Gray and Jenkins (2004) put this down to a government commitment to a mixed rhetoric of local choice and national minimum standards which give the impression that new localism policy is more about 'checking' than 'doing' in an increasingly audit and managerially driven society: 'what matters is what works may well have become what matters is what is shown to work' (p. 287, emphasis added). As such the UK Local Government Association has recently argued that centralism continues to inhibit 'local choice and decisions, stifles innovation... wastes public money and erodes democracy itself (LGA, 2006, p. 11).

That said, 'pragmatism' has emerged as the 'common sense' view and 'overarching ethos' within an increasingly complex public sector. New localism policy has shaken up and destabilised existing ways of doing but not brought about fundamental change despite promises to plan-in pragmatism to local policy processes (Coaffee and Healey, 2003; Johnston, 2005). This situation is summed up in urban policy through a recent British Urban Regeneration Association report (2006, p. 11) entitled Local Government, New Localism and the Delivery of Regeneration, which argued that

If new localism leads to vibrant administrations with good leadership, this will be welcomed. However, there is a pervading sense that Westminster is giving with one hand, but maintaining a very strong grip on local government with the other. It is questionable 
whether a substantial and meaningful devolution of power to the local level is occurring at the rate necessary to facilitate and hasten the delivery of regeneration.

More recently the ongoing government proposals, based in large part on the French Commune model - so-called 'Double Devolution' - argues for a more mature model of centre-local relations and is attempting to extend new localism ideas, and is seeking to speed up this transformation through an overarching political pragmatism. This will hopefully mean a greater commitment to the devolution of power and responsibility from central government and the increase in local citizen 'choice and voice' below the town hall governance level and into neighbourhoods in as pragmatic and pluralistic-a-way as possible. As the UK Minister for Communities and Local Government, noted in 2005 , pragmatism is a core feature of local government reform:

What is clear...is that there is no single model for devolution to neighbourhood level. It is not possible sitting in Whitehall [central government] what approach will work for what community under what circumstances; that is a matter for councils and other public service providers in consultation with their residents (ODPM, 2006, p. 16).

Such a call comes at a time when a plethora of public sector reviews, are focusing on creating a 'strategic and lean' central government which gives constrained discretion to localities (Smith Institute, 2006, pp. 11-12). Such reviews consistently highlight that it is the interference from central government that is holding pragmatic localism back, and where 'the gravitational pull of government grants, targets and performance management has created an unhealthy situation where local councils are too often focused on the wishes of ministers...rather than their owns citizens needs and preferences' (Lyons Inquiry, 2006, p. 3).

The key question here appears to be the extent to which national derived principles and local pragmatic action can be balanced within the practice of public sector management. This will determine whether a truly pragmatic localism emerges, personalised to locally specific arenas of action, or whether embedded cultures of local government practice re-stabilise without sufficient flexibility to produce more effective, deliberative and democratic ways of working.

\section{References}

Bailey, N., 2003. Local Strategic Partnerships in England. The continuing search for collaborative advantage, leadership and strategy in urban governance. Planning Theory and Practice 4 (4), 443-457.

Bailey, N., 2005. Transformation or bureaucratization? The changing role of community representation in Local Strategic Partnerships in England. Journal of Civil Society 1 (2), 147-162.

Berg, A.M., 2006. Transforming Public Services - transforming the public servant. International Journal of Public Sector Management 19 (6), $556-568$.
Bernstein, R.J., 1960. John Dewey. On Experience, Nature and Freedom. Representative Selections. The Liberal Arts Press, New York.

Bernstein, R., 1992. The New Constellation. MIT Press, Cambridge, MA. Blair, T., 1998. The Third Way. Fabian Society, London.

Boddy, M., Fudge, C. (Eds.), 1984. Local Socialism? Macmillan, London.

British Urban Regeneration Association (BURA), 2006. Local Government, New Localism and the Delivery of Regeneration. BURA, London.

Cabinet Office, 1999. Policy Making for the 21st Century. Cabinet Office, London.

Carpenter, J., 2005. Local path to power. Regeneration and Renewal 21 (April), 16-17.

Clarke, J., 1999. Coming to terms with culture. In: Dean, H., Woods, R. (Eds.), Social Policy Review, vol. 11. Social Policy Association, Luton, pp. 71-89.

CLES, 2005. Flexible Friends. New Start, 16 December, 12-13.

Coaffee, J., 2004. Re-scaling regeneration - experiences of merging areabased and city-wide partnerships in urban policy. The International Journal of Public Sector Management 17 (5), 443-461.

Coaffee, J., 2005a. New localism and the management of regeneration. International Journal of Public Sector Management 18 (2), 108-113.

Coaffee, J., 2005b. 'Shock of the new' - complexity and emerging rationales for Partnership working. Public Policy and Administration 20 (3), 23-41.

Coaffee, J., Healey, P., 2003. 'My Voice My Place': tracking transformations in urban governance. Urban Studies 40 (10), 1960-1978.

Coaffee, J., Johnston, L., 2005. The management of local government modernisation - area decentralisation and pragmatic localism. International Journal of Public Sector Management 18 (2), 164-177.

Considine, M., Lewis, J., 1999. Governance at ground level: the frontline bureaucrat in the age of markets and networks. Public Administration Review 59 (6), 467-478.

Corry, D., Stoker, G., 2002. New Localism Refashioning the CentreLocal Relationship. NLGN, London.

Corry, D., Hatter, W., Parker, I., Randle, A., Stoker, G., 2003. Joining-up Local Democracy - Governance Systems for a New Localism. NLGN, London.

Davies, J., 2004. Conjuncture or disjuncture? An institutional analysis of local regeneration partnerships in the UK. International Journal of Urban and Regional Research 28 (3), 570-585.

Department of Communities and Local Government (DCLG), 2005. A Process Evaluation of the Negotiation of Pilot Local Area Agreements. HMSO, London.

Department of Communities and Local Government (DCLG), 2006. Local Area Agreements Enabling Measure requests (round 2) HMSO, London.

Department of Communities and Local Government (DCLG), $2007 \mathrm{a}$. Developing the Future Arrangements for Local Area Agreements. HMSO, London.

Department of Communities and Local Government (DCLG), $2007 \mathrm{~b}$. Evidence of Savings, Improved Outcomes, and Good Practice Attributed to Local Area Agreements. HMSO, London.

Department of Environment, Transport and the Regions (DETR), 1998. The Local Government White Paper, Modern Local Government in Touch with the People. HMSO, London.

Department of Environment, Transport and the Regions (DETR), 2000. Preparing Community Strategies: Guidance to Local Authorities. HMSO, London.

Dewey, J., Bentley, A.F., 1949. Knowing and the known. In: Boydston, J.A. (Ed.), Latter Works, vol. 16. Southern Illinois University Press, Carbonate and Edwardsville, pp. 1-294.

Diamond, J., 2004. First it was 'going local' in the 1980s and now its 'localism' - what have we learnt and why does it matter. The Challenges of Localism. Regional Studies Association, London, pp. $18-21$.

Dickson, N., 1999. What is the third way? BBC News website 27 September: www.new.bbc.co.uk/1/hi/uk_poltics/458626.stm (accessed 28 September 1999). 
Dickstein, M. (Ed.), 1998. The Revival of Pragmatism. Duke University Press, Durham, NC.

Diggens, J., 1994. The Promise of Pragmatism. University of Chicago Press, Chicago.

Driver, S., Martell, L., 1998. New Labour: Politics after Thatcherism. Polity Press, Cambridge.

Dryzek, J.S., 2004. Pragmatism and democracy: in search if a deliberative publics. Journal of Speculative Philosophy 18 (1), 72-79.

Department of Transport, Local government and the Regions (DTLR), 2001. Local Strategic Partnerships - Government Guidance. DTLR, London.

Elkjaer, B., 2004. Organizational Learning: The 'Third Way'. Management Learning 35 (4), 419-434.

Etzioni, A. (Ed.), 1998. The Essential Communitarian Reader. Rowman \& Littlefield Publishers, Lanham, MD.

Fry, R.B., 1989. Mastering Public Administration. Chatham House, Chatham, NJ.

Garrison, J., 2000. Pragmatism and Public Administration. Administration and Society 32 (4), 458-477.

Giddens, A., 1998. The Third Way: The Renewal of Social Democracy. Polity Press, Cambridge.

Gray, A., Jenkins, B., 2004. Government and administration: too much checking, not enough doing? Parliamentary Affairs 57 (2), 269-287.

Hambleton, R., Sweeting, D., 2004. US-style leadership for English local government. Public Administration Review 64 (4), 474-488.

Haywood, A., 2000. Key Concepts in Politics. Palgrave, Basingstoke.

Hildebrand, D.L., 2005. Pragmatism, neopragmatism and public administration. Administration and Society 37 (3), 345-359.

Hollinger, R., Depew, D. (Eds.), 1995. Pragmatism: From Progressivism to Postmodernism. Praeger, Westport, CT.

Hutton, W., 1995. The State We're In. Jonathan Cape, London.

James, W., 1907. Pragmatism: A New Name for Some Old Ways of Thinking. Riverside Press, Cambridge, MA.

Johnston, L., 2005. Waking up the Sleeping Giant: change management, policy transfer and the search for collaboration. Public Policy and Administration 20 (3), 69-89.

Leach, S., Wilson, D., 2004. Urban Elites in England: new models of executive governance. International Journal of Urban and Regional Research 28 (1), 134-149.

Local Government Association (LGA), 2005. Leading Localities - Local Area Agreements. LGA, London.

Local Government Association (LGA), 2006. Closer to People and Places - A New Vision for Local Government. LGA, London.

Lister, R., 2001. New Labour: a study in ambiguity from a position of ambivalence. Critical Social Policy 21 (4), 425-447.

Loughlin, J. (Ed.), 2001. Sub-national Democracy in the European Union Challenges and Opportunities. Oxford University Press, Oxford.

Lowndes, V., 2003. Between rhetoric and reality: does the 2001 White paper reverse the centralising trend in Britain? Local Government Studies 28 (3), 135-147.

Lowndes, V., Wilson, D., 2003. Balancing revisability and robustness? A new institutionalist perspective on local government modernization. Public Administration 81 (2), 275-298.

Lyons Inquiry, 2006. National Prosperity, Local Choice and Civic Engagement: A New Partnership Between Central and Local Government for the 21st Century. HMSO, Norwich.

Maude, F., 1998. No such thing as a third way. Speech to the social market foundation, cited in the Independent Newspaper. August 4.

Miller, H.T., 2005. Residues of foundationalism in classic pragmatism. Administration and Society 37 (3), 360-374.

Morgan, K., 2002. The new regeneration narrative - local development in the multi-level polity. Local Economy 17 (3), 191-199.

Morphet, J., 2004. The New Localism. Town and Country Planning, October 2004, pp. 291-293.

ODPM, 2004. Local Area Agreements: A Prospectus. ODPM, London.

ODPM, 2006. Empowerment and the Deal for Devolution: Speech by Rt Hon David Milliband MP Minister for Communities and Local Government ODPM, London.
Page, E.C., 1991. Localism and Centralism in Europe. Oxford University Press, Oxford.

Powell, M., 1999. New labour, new welfare stare? Social Policy and Administration 32 (1), 1-13.

Powell, M., 2000. New Labour and the third way in the British welfare state: a new and distinctive approach? Critical Social Policy 20 (1), 39 60.

Powell, M., 2004. In Search of New and Old Localism. Paper presented to the ESPAnet conference, Oxford, 9-11 September.

Pratchett, L., 2004. Local autonomy, local democracy and the new localism. Political Studies 52, 358-375.

Putnam R.D., 2000. Bowling Alone: The Collapse and Revival of American Community Simon and Schuster, New York.

Randle, A., 2005. Councils Embracing Localism. New Local Government Network, London.

Rhodes, R.A.W., 1996. The new governance: governing without government. Political Studies 44 (4), 652-667.

Rorty, R., 1982. Consequences of Pragmatism: Essays: 1972-1980. University of Minnesota Press, Minneapolis.

Rorty, R., 1991. Objectivity, Relativism and Truth. Cambridge University Press, Cambridge.

Rorty, R., 1999. Philosophy and Social Hope. Penguin, London.

Rowe, M., 2006. Abusive partnerships: new forms of governance, new forms of abuse? International Journal of Sociology and Social Policy $26(5 / 6), 207-219$.

Scanlon, C., 2001. A step to the left or just a jump to the right? Making sense of the third way on government and governance. Australian Journal of Political Science 36 (3), 481-498.

Shields, P.M., 1996. Pragmatism: exploring public administration's policy imprint. Administration and Society 28 (3), 390-411.

Shields, P.M., 2003. The community of inquiry: classical pragmatism and public administration pragmatism. Administration and Society 35 (5), 510-538.

Shields, P.M., 2004. Classical pragmatism: engaging practitioner experience. Administration and Society 36 (3), 351-361.

Smith, S.J., 1984. Practising humanistic geography. Annals of the Association of American Geographer 74 (3), 353-374.

Smith, M.J., 2001. Conclusion: the complexity on New Labours'. In: Ludlam, S., Smith, M.J. (Eds.), New Labour in Government. Macmillan, Basingstoke, pp. 256-267.

Smith Institute, 2006. Double Devolution: The Renewal of Local Government. In: Mulgan, G., Bury, F. (Eds.), Smith Institute, London.

Snider, K.F., 2000. Expertise of experimenting? Pragmatism and American public administration: 1920-1950. Administration and Society 32 (4), 329-354.

Social Exclusion Unit, 1998. Bringing Britain Together. HMSO, London.

Sorabji, D., 2005. The accidental renaissance of local government. Local Economy 20 (1), 6-12.

Southern, A., 2001. What matters is what works? - The management of regeneration. Local Economy 16 (4), 264-271.

Stever, J.A., 2000. The parallel universes: pragmatism and public administration. Administration and Society 32 (4), 453-457.

Stoker, G., 2004. New localism, progressive politics and democracy. In: Gamble, A., Wright, T. (Eds.), Restating the State. Blackwell, Oxford, pp. 117-129.

Stolcis, G.B., 2004. A view from the Trenches comment on Miller's "Why old pragmatism needs an upgrade". Administration and Society 36 (3), 362-369.

Sullivan, H., Gillanders, G., 2005. Stretched to the limit? The impact of local public service agreements on service improvement and central-local relations. Local Government Studies 31 (5), 555574.

Taylor, M., 2003. Public Policy in the Community. Palgrave Macmillan, Basingstoke.

Temple, M., 2000. New Labour's Third Way: pragmatism and governance. British Journal of Politics and International Relations 2 (3), $302-325$. 
Tewdwr-Jones, M., Mophet, J., Allmendinger, P., 2006. The contested strategies of local governance: community strategies, development plans and local government modernisation. Environment and Planning A $38,533-551$.

Van der Pennan, T., 2005. Actor strategies in decentralized policy networks. Journal of Housing and the Built Environment 20, 310-315.

Vize, R., 2006. Is it breaking point for the LAAs? Local Government Chronicle 19 (January), 8-9.

Webb, J.L., 2004. Comment on Hugh T. Miller's "Why old pragmatism needs an upgrade". Administration and Society 36 (4), 479-495.

Wilson, D., 2003. Unravelling control freakery: redefining central-local relations. British Journal of Politics and International Relations 5 (3), $317-346$.
Wilson, D., Game, C., 2002. Local Government in the United Kingdom, third ed. Palgrave/Macmillan, Ebbw Vale.

Young, K., 2005. Local public service agreements and performance incentives for local government. Local Government Studies 31 (1), 3 20.

Zanetti, L.A., Carr, A., 2000. Contemporary pragmatism and public administration: exploring the limitations of the "Third Productive Reply”. Administration and Society 32 (4), 433-452. 